\title{
FIGURAÇÕES DANTESCAS SOBRE A AMAZÔNIA O NORTE DE GOIÁS NA OBRA VIAGEM CIENTÍFICA
}

\author{
DANTESCAS FIGURATIONS ABOUT THE AMAZON \\ THE NORTH OF GOIÁS IN THE WORK SCIENTIFIC JOURNEY
}

\author{
Olivia Macedo Miranda de Medeiros ${ }^{1}$ \\ Euclides Antunes de Medeiros ${ }^{2}$
}

\begin{abstract}
Resumo: Nesse artigo discutiremos alguns aspectos da estrutura poética e retórica da obra "Viagem Científica: pelo norte da Bahia, sudoeste de Pernambuco, sul do Piauí e de norte a sul de Goiás" (1916), escrita pelos médicos do Instituto Manguinhos, Artur Neiva e Belisário Pena. Referenciando nossa análise na concepção de história como narrativa e discurso ficcionalizado de Hayden White e na ideia de literatura como pegada de escrita de Roland Barthes, buscamos compreender como as interpretações presentes nessa obra formularam paisagens de desolação e de tragicidade dantesca sobre o norte de Goiás, atualmente estado de Tocantins, a partir do primeiro quartel do século XX. As análises realizadas evidenciaram que os referidos médicos territorializaram os sertanejos goianos em uma rede de sentidos vinculada aos signos da doença, da pobreza e da inaptidão.
\end{abstract}

Palavras-chave: Amazônia; viagem científica; Norte de Goiás; retórica; paisagens dantescas.

Abstract: In this article we will discuss some aspects of the poetic and rhetorical structure of the work "Scientific Trip: across northern Bahia, southwestern Pernambuco, southern Piauí and north to south Goiás" (1916), written by the doctors of the Manguinhos Institute, Artur Neiva and Belisário Pena. Referring to our analysis in the conception of history as Hayden White narrative and fictionalized discourse and in the idea of literature as Roland Barthes' writing footprint, we seek to understand how the interpretations present in this work formulated landscapes of desolation and Dantesque tragicity over northern Goiás currently state of Tocantins, from the first quarter of the 20th century. The analyzes carried out showed that the referred doctors territorialized the people of Goiás in a network of meanings linked to the signs of illness, poverty and disability.

Keywords: Amazon; scientific travel; Northern Goiás; rhetoric; Dantesque landscapes.

\footnotetext{
${ }^{1}$ Professora Adjunta dos Cursos de História na Universidade Federal do Tocantins (UFT), Campus de Araguaína. Doutora em História pela Universidade Federal de Uberlândia (UFU) e Professora do Programa de Pós-Graduação em Estudos de Cultura e Território - PPGCULT-UFT. Editora da Revista Escritas do Curso de História da UFT/Araguaína. Membro do Coletivo de Mulheres Raimundas. Pesquisas na área de História e Literatura, com destaque para História Social, Linguagens literárias e Comunidades. E-mail: oliviammmedeiros@gmail.com ${ }^{2}$ Doutor em História pela Universidade Federal de Uberlândia (UFU) e Professor Adjunto dos Cursos de História na Universidade Federal do Tocantins (UFT), Campus de Araguaína. Professor do Programa de Pós-Graduação em Estudos de Cultura e Território - PPGCULT-UFT. Editor da Revista Escritas do Curso de História da UFT/Araguaína. Pesquisas na área de História, com destaque para História Regional, Literatura, Memória e Violência. E-mail: euclides.antunes@uol.com.br
} 


\section{Introdução}

Artur Neiva nasceu em 22 de março de 1880, em Salvador, Bahia. Formou-se médico pela Faculdade de Medicina do Rio de Janeiro. Depois da sua formatura, ingressou no Instituto de Manguinhos ${ }^{3}$, no qual, em conjunto com outros cientistas, executou trabalhos na área de entomologia. Depois de retornar de viagem dos Estados Unidos, onde fora especializar-se nessa área no ano de 1910, assume a chefia, em 1912, da expedição ${ }^{4}$ que dá origem à obra "Viagem Científica: pelo norte da Bahia, sudoeste de Pernambuco, sul do Piauí e de norte a sul de Goiás", publicada em 1916.

Belisário Augusto de Oliveira Pena, nascido em 29 de novembro de 1868, em Barbacena-MG, era filho homônimo do visconde de Carandaí e de Lina Leopoldina Lage Duque. Formou-se em medicina, atuando em Barbacena e Juiz Fora-MG. Em 1904, Pena prestou concurso para a área sanitária no Instituto Maguinhos, sendo nomeado para o cargo de inspetor sanitário 5 .

Em 1912, Belisário Pena participou de expedição, juntamente com Artur Neiva, às zonas atingidas pela seca nos estados de Pernambuco, Piauí, Bahia e Goiás para investigar a atuação, em campo, do protozoário responsável pela transmissão da Doença de Chagas e, concomitantemente, do protozoário que à época julgava-se ser o causador do bócio. Os resultados de pesquisa e, principalmente, das observações e impressões sobre a cultura e a sociedade sertaneja durante essa expedição deram origem à obra Viagem Científica, assinada por ambos os médicos.

\footnotetext{
${ }^{3}$ Segundo Nísia Trindade Lima, Manguinhos é “um bairro em que foi construída em 1900 a sede da atual Fundação Oswaldo Cruz. Originalmente denominado Instituto Soroterápico Federal, pouco tempo depois passou a se chamar Instituto Oswaldo Cruz. Manguinhos tornou-se um nome extraoficial e de forte apelo simbólico ainda hoje utilizado para designar esse centro de pesquisas biomédicas" (2013, p. 131).

${ }^{4}$ Após participar dessa primeira expedição, Neiva alcança notoriedade ao participar de outras expedições sanitaristas pelo interior do Brasil, tornando-se um incentivador do trabalho de campo na área de pesquisa das ciências médicas e biológicas no país. Foi o primeiro diretor do Instituto Biológico, de 1927 a 1931. Neiva, além de seus estudos nas áreas de botânica, zoologia e patologia, era político: tendo sido interventor, a convite de Getúlio Vargas, em sua cidade natal no ano de 1931 e, posteriormente, em 1934, deputado pelo estado da Bahia. Faleceu em 1943, aos 63 anos de idade.

${ }^{5}$ Durante sua carreira, Belisário Pena prestou importante contribuição ao serviço profilático de diversas epidemias, como a varíola, a febre amarela e o impaludismo. Além disso, contribuiu de forma definitiva com as políticas de saneamento no Brasil, vindo a publicar a obra seminal Saneamento no Brasil (1918). A repercussão dessa obra levou à criação da Liga Pró-saneamento do Brasil, que agregou diversos intelectuais brasileiros, entre eles os próprios Neiva e Pena, Oswaldo Cruz e Monteiro Lobato. Aposentou-se em 1932. Filiando-se ao movimento integralista, envolveu-se na fracassada tentativa de golpe em 1938. Depois desse episódio Belisário Pena deixou a política e transferiu-se para sua fazenda no interior do Rio de Janeiro, vindo a falecer em novembro de 1939.
} 
Segundo Nísia Trindade Lima essa obra é uma das precursoras "da perspectiva médica adotada ao se olhar para os sertões brasileiros [que] transformam-se numa questão da cultura e da política compartilhada por diferentes intelectuais e outros atores sociais". (2013, p. 146). De fato, analisar obras de viagens científicas, tal qual a de Neiva e Pena, como base para a formação do pensamento social brasileiro é uma tarefa à qual historiadores e sociólogos têm se lançado desde longo tempo, porém, pouco se tem trabalhado essas narrativas da perspectiva da análise de seus aspectos retóricos, poéticos e estéticos.

Assim, buscando adentrar nessa seara, pretendemos problematizar neste artigo a linguagem poética e retórica da obra Viagem Científica (1916), sobretudo na parte que narra aspectos relativos ao norte de Goiás, atual estado de Tocantins ${ }^{6}$, com o objetivo de compreender como foram construídas as paisagens, as imagens e as alegorias a partir das quais foram territorializadas, simbolicamente, as pessoas que viviam nesse região.

A ideia de território que mobilizamos nesse texto baseia-se na concepção dos filósofos Félix Guattari e Sueli Rolnik, os quais concebem essa noção em um sentido muito amplo, considerando que:

Os seres existentes se organizam segundo territórios que os delimitam e os articulam aos outros existentes e aos fluxos cósmicos. O território pode ser relativo tanto a um espaço vivido, quanto a um sistema percebido no seio do qual um sujeito se sente "em casa". O território é sinônimo de apropriação, de subjetivação fechada sobre si mesma. Ele é o conjunto de projetos e representações nos quais vai desembocar, pragmaticamente, toda uma série de comportamentos, de investimentos, nos tempos e nos espaços sociais, culturais, estéticos, cognitivos". (GUATTARI; ROLNIK, 1986, p. 323).

Ou seja, o território é concreto e físico, mas também é psicológico, imaginado, literário, estético e subjetivo. No caso das regiões amazônicas e especialmente do Norte de Goiás, os processos estéticos, discursivos e poéticos construídos narrativamente por Artur Neiva e Belisário Pena formularam uma retórica que territorializou essa região e os homens que ali viviam à margem do processo civilizacional. Sobre a relação entre poética, estética e território, Rogério Haesbaert esclarece alguns aspectos:

Como a escolha de um símbolo não pode privar-se de toda a referência ao "real", podemos associar essas reflexões ao nosso campo, a Geografia, e lembrar que muitos espaços expressam muito mais do que a manifestação concreta de seus prédios, estradas, montanhas. Neles há "espaços", ou se preferirem territórios [...] de um caráter particular, especial, cuja significação extrapola em muito os seus limites físicos. [...] Espaços a partir dos quais se cria uma leitura simbólica que pode ser sagrada, poética, ou simplesmente folclórica, mas que de qualquer forma emana uma

\footnotetext{
${ }^{6}$ A partir de 1988 a região norte de Goiás emancipa-se desse estado, passando a constituir o estado de Tocantins, o qual passou a integrar a macro região Norte e a Amazônia Legal.
} 
apropriação estética, específica, capaz de fortalecer [e criar] uma identidade territorial. (HAESBAERT, 1997 p. 24)

Não é nossa intenção nesse texto discutir aspectos identitários do território, mas observar, a partir da abordagem de Haesbaert, que a ideia de um espaço formulado a partir de sensibilidades estéticas cria leituras simbólicas e, nesse sentido, configura e figura paisagens capazes de recriar o mundo social segundo processos específicos de territorialização. Assim, no que concerne à obra de Neiva e Pena, suas estratégias narrativas situaram no âmbito da linguagem a constituição de uma estética geohistórica que objetivava deslocar os signos que davam sentido ao território norte goiano para uma zona de estigmatização. Dessa forma, nos parece que a questão central a ser investigada é a identificação e problematização dos artifícios de ficcionalização poética e retórica que são mobilizados por Neiva e Pena para construir a referida zona de exclusão e estigmatização.

Contudo, antes de iniciarmos tal discussão, faz-se necessário esclarecer que não estamos concebendo a obra Viagem Científica como um texto ficcional tout court, mas como um texto que, em alguma medida, é também literário e, nesse sentido, ficcionalizado. Por outras palavras, concebemo-la como composta por uma dimensão inventada, mobilizadora de uma linguagem que, em uma arquitetura poética e retórica, constituiu signos e semânticas por meio dos quais os sertões goianos foram traduzidos. Acerca do modo como estamos tomando o texto de Viagem Científica, nos baseamos no semiólogo Roland Barthes ao ensinar que a literatura não é "um corpo ou uma sequência de obras [e] nem mesmo um setor de comércio ou de ensino, mas um grafo complexo de pegadas de uma prática: uma prática de escrever” e por isso ela é também toda escrituração (2007, p. 16).

Ou seja, todo texto é grafo, é uma prática de escrita que, de um lado, congrega experiências, dados, informações, imaginários, cognoscibilidades e que, de outro, registra algo mais fugidio e pouco observado relativo aos domínios da linguagem e das articulações que essas mesmas linguagens fazem entre modos, formas, estilos, efeitos estéticos, discursos, retóricas, os quais em seu conjunto estão configurados em um núcleo estrutural poético. Além disso, a literatura, segundo Barthes, não pode ser inscrita em um campo único de conhecimento, pois todo texto circula entre saberes, afinal:

O paradigma que prop[õe] não segue a partilha das funções; não visa a colocar de um lado os cientistas, os pesquisadores, e de outros os escritores, os ensaístas; ele sugere, pelo contrário, que a escritura se encontra em toda parte onde as palavras tem sabor ([pois] sabor e saber têm em latim, a mesma etimologia) (BARTHES, 2007, p. 20). 
Para Barthes, a literatura, ao ser tomada como uma escrita de sentido amplo, não podendo ser restringida aos limites da escrituração ficcional, constitui-se em um conhecimento que circula entre saberes e, mais que isso, circula entre cognoscibilidades e paradigmas narrativos diversos. Assim, nesse artigo, partimos da ideia de que o texto de Viagem Científica seria uma escritura cuja força se encontra entre as pressões e os limites constituídos por seu hibridismo, uma prática que se coloca entre fronteiras que muitas vezes se pretendem rígidas, mas que não suportam um olhar mais acurado para os limites de sua própria construção sem que se perceba que sua feitura pressupõe a invasão dos terrenos de outros saberes.

Entretanto, a simples definição como construção textual não suprime algumas questões quanto ao caráter dessa construção, conduzindo-nos à primeira fronteira dessa prática: a prática de escrever remete ao ato de narrar, de contar uma história e, para tal, o narrador mobiliza linguagens que pretendem constituir significados. Por outras palavras, quando os médicos Artur Neiva e Belisário Pena escreveram e depois publicaram Viagem Científica, o texto dessa obra constituiu um ato narrativo, carregado de signos que formavam uma rede de sentidos que não apenas representava os resultados de suas pesquisas científicas pelos sertões brasileiros, mas também estava impregnada de significados construídos a partir dos usos e modos pelos quais a linguagem retórica e a poética foram mobilizadas pelos autores. Dessa forma, ao inscrever os sertões goianos em uma dada configuração narrativa, o texto de Viagem Científica compõe uma territorialização simbólica dos sertanejos norte-goianos, circunscrevendo-os em uma rede definida de significados.

\section{Os signos da desolação na figuração da natureza do norte de Goiás}

Publicada em 1916, a obra Viagem Científica é fruto do relatório produzido por Neiva e Pena sobre as experiências dessa expedição pelos estados em referência e, como esclarece a historiadora Nísia Trindade Lima, em Um sertão chamado Brasil (2013), "não foi concebida originalmente como um retrato do Brasil, mas como artigo médico referido a uma viagem científica" (2013, p. 300). Pertinentemente, Lima expõe que a narrativa constante no relatório tinha a pretensão de se apresentar como um texto objetivo sobre as patologias que, segundo Neiva e Pena, assolavam os sertões que iam de Pernambuco a Goiás. Mas, ainda segundo ela, por sua repercussão entre a intelligentsia da segunda década do século XX, assumiu crescente importância no debate sobre os rumos políticos do país, "contribuindo para que o tema da 
doença e a proposta da reforma da saúde [...] alcançassem grande visibilidade" (LIMA, 2013, p. 300).

Diferentemente de Euclides da Cunha, que concebeu o intercâmbio entre ciência e literatura como uma vantagem narrativa, Artur Neiva e Belisário Pena buscaram transpor para o texto de Viagem Científica os princípios metodológicos da ciência médica. Atuando no Instituto Manguinhos e desenvolvendo trabalhos que envolviam a pesquisa da doença de Chagas, ambos os médicos se sentiam frustrados por não conseguirem reproduzir em laboratório o comportamento dos protozoários que eles julgavam fossem os causadores da referida doença. É nesse contexto que surge a oportunidade da viagem aos sertões, possibilitando que fosse "reinceta[da] as experiências interrompidas, sobre o papel da Triatoma sordida [causador do bócio] na transmissão de Chagas" (NEIVA; PENA, 1999, p. 118).

Sem dúvida, a criação de um retrato das áreas do interior brasileiro relaciona-se à construção do tropo social do sertão como patologia, remontando tanto às viagens científicas realizadas por Manguinhos quanto à adoção da perspectiva médica como instrumento e interpretação social, cultural e política, como defende Lima (2013). Contudo, para além dessa "perspectiva médica" há no texto de Viagem Científica uma dimensão literária urdida em articulação com figuras de linguagem, estilizações de escrita e modos ficcionais que forjam muitas das interpretações presentes nessa obra.

O estilo dos médicos, nesse sentido, parece imbricar-se com os modelos de pesquisa da medicina tropical que demarcava a necessidade de voltar o olhar para as "condições geográficas dos trópicos, ou seja, para os fatores que contribuiriam para a presença e a proliferação dos insetos transmissores das doenças", como esclarece Júlio Cesar Schweickardt (2010, p. 03). Pensar a descrição do mundo natural para esses médicos era posto quase sempre em uma escala reduzida das observações, privilegiando os animais invisíveis a olho nu - os protozoários e insetos - e, a partir de então, ampliando a escala para os ambientes mais amplos e finalmente alcançando o homem sertanejo: personagem que alarmava a nação pelo "número de 'papudos' [que era] enorme, [pois] o bócio alcança[va] proporções não vistas até então [...].” (NEIVA; PENA, 1999, p. 119).

Se, em 1912, Neiva e Pena não tinham dimensão das consequências de sua viagem para a construção do pensamento social brasileiro, em 1916, quando da publicação do referido relatório, pareciam já ter compreendido a função paradigmática da inserção em seu texto dos "conhecimentos advindos da geografia, da cultura e da história, fundamentais para a compreensão da incidência de determinadas doenças e sua distribuição no tempo e no espaço" 
(LIMA, 2013, p. 305). Ao articularem esses conhecimentos às suas narrativas, os médicos deixaram entrever, ao leitor, o fato de terem adentrado em novas searas, nas quais os objetivos de seu trabalho transformaram-se de científicos também em retóricos:

Não agradará certamente a franqueza com que expomos nossa impressão, mas
julgamos ser isso um dever de consciência e de patriotismo. É indispensável dizer a
verdade, embora dolorosa e cruciante e não iludir de forma alguma a nação para que
não sofram os jovens a triste desilusão por que nós passamos quando através [d]os
livros e romances, havíamos imaginado o Brazil Central um paiz privilegiado, de
terras ubérrimas, matas infindáveis (NEIVA; PENA, 1999, p. 222).

A natureza e o solo foram pintados pelos médicos com tons cinza que evocavam imagens "dolorosas e cruciantes". Para os dois, narrar os sertões goianos seria antes de tudo restringir, ou melhor, extirpar as cargas de imaginação e devolver ao relato um caráter cientificista. Contudo, a objetividade almejada pelos médicos, quando transformada em texto, assumiu um caráter literário que se aproximava estilisticamente ao Naturalismo por sua aspereza e aridez ao representar os elementos naturais e as interposições do homem na natureza. Optando por iluminar a face que destacava a seca e o descampado, esses médicos tecem suas descrições da paisagem goiana:

A grande campina entre os geraes baianos e a vila do Duro (norte de Goiás) é revestida quasi completamente de gramináceas; não existem em toda aquela extensão árvore alguma ou arvoredo que dê sombra. Disseminados aqui, ali, acolá, vêm-se pés de Caratella americana e dos representantes dos gêneros Kielmeyera MART e Plumeria TOURN [...] d[and]o o tom da paisagem (NEIVA; PENA, 1999, p. 82).

Referindo-se aos nomes científicos das espécies botânicas e aludindo aos seus descobridores, Neiva e Pena constituíram uma representação narrativa pautada pela linguagem científica que perseguem, mas, ao mesmo tempo, evocam os signos da ausência: não havia árvores, não havia sombras, pois não tinham "atravessado matas em toda região percorrida" (1999, p. 84). Esse vasto espaço lacunar, onde nada havia, foi preenchido pelos médicos, do ponto de vista narrativo, com signos que delinearam a paisagem, que adentra a retina do leitor, como desnudada, vazia, desertificada, desolada.

Descrever a ausência das matas e das árvores, per si, já enunciava a imagem do sertão goiano como uma terra estéril, porém, para Artur Neiva e Belisário Pena, era necessário ir além. Assim, buscaram ampliar os signos da ausência, presentes na figuração da paisagem, para uma representação do Norte de Goiás como avatar da pobreza, considerando que "quanto à fertilidade do solo goiano [...] o norte é muito pobre até de pastagens o que é fácil de verificar pelo tamanho do gado, em contraste com o que se verifica em certas zonas do Piauhy (NEIVA; PENA, 1999, p. 84). 
O emprego da preposição "até" esclarece o grau de intensidade que os médicos desejavam imprimir à semântica de um sertão goiano pobre, à medida que, na percepção do médicos, na ausência das matas e das árvores, até as pastagens, que costumavam abundar na região de campos do Brasil Central, eram insignificantes em Goiás, o que se achava plenamente justificado pelo tamanho diminuto do gado.

O método descritivo da natureza e as generalizações assumiram um papel importante na formulação do estilo narrativo que figurou Goiás como um espaço desolado e improdutivo. Os cientistas/médicos eram também cientistas/viajantes e carregavam em si um pouco daquela expectativa dos viajantes do século XIX em relação à observação. Respondendo a esse espírito observador, as comissões do século XX seriam como as expedições do século XIX que, indo “cada vez a regiões mais longínquas [...] são observadas atentamente. Mas sempre como objetos de estudo, não de estímulo à autorreflexão ou ao êxtase” (SÜSSEKIND, 1990, 109).

Flora Süssekind escreve sobre as viagens do século XIX e suas orientações descritivas, porém mesmo que não se refira às comissões científicas do século XX, é possível encontrar vestígios, em Neiva e Pena, dessa tentativa de afastar qualquer lastro de subjetividade dos “objetos" observados. Sobre esse aspecto, encontramos em Émile Zola e na construção da proposta naturalista, esclarecimentos pertinentes. Segundo Zola, a literatura ficcional de vanguarda no século XIX deveria fundamentar-se na busca da verdade e na luta contra "a doença romântica" (ZOLA, 1979, p. 59). Interpretando alguns aspectos do Naturalismo na perspectiva de Zola, Raquel Lima Silva explica que, para esse literato, o "cientista é o poeta que substitui as hipóteses da imaginação pelo estudo exato das coisas e dos seres, [pois] o naturalismo não é somente uma estética literária, mas também um método de pensamento", ou seja, Zola compreenderia o "Naturalismo como a fórmula da ciência moderna aplicada à literatura", (SILVA, 2010, p. 99).

No caso de Viagem Científica, o tom naturalista surgiria como a tentativa dos médicos de se apropriarem do método de observação experimental e, dessa forma, procurarem pautar sua escrita no "que t[inham] observado, em [suas] viagens" e apresentando-se como críticos do matiz romântico com o qual os sertões eram narrados (NEIVA; PENA, 1999, p. 221). Vejamos:

[...] No nosso longo trajeto, não lobrigamos as proclamadas riquezas minerais, com que nos enchem a memória e a imaginação, mapas e livros. [...] Concorrem muito para esse estado de cousas as falsas informações dos que viajam por essas regiões, pintando em linguajem florida e imaginosa, quadros de intensa poesia de vida bucólica feliz e farta (NEIVA; PENA, 1999, p. 221-222). 
Afastando-se da "doença romântica", Neiva e Pena buscaram expor os limites dessa estética para registrar a "verdade" e para construir relatos científicos. Na perspectiva de ambos, os narradores dos sertões goianos deveriam abrir mão "da poesia das paisagens e dos panoramas", porém, ao contrário do que propugnaram, quando chegou suas oportunidades de narrarem a paisagem desses sertões, recorreram a artifícios de linguagem e recursos figurativos que intensificaram a carga poética e subjetiva do relato ao comporem "os sertões, que conhece[ram] [como] pedaços do purgatório [...] onde se purgam os pecados em vida [...]”. (NEIVA; PENA. 1999, p. 222). O caráter poético do texto é forjado pelos signos trágicos com os quais Neiva e Pena buscaram aprofundar os significados de uma natureza desolada, infrutífera e desértica; preparando-a, a natureza, para ser preenchida com os efeitos estéticos que isolaram o homem goiano nesse "pedaço de purgatório".

\section{0 discurso civilizador e os efeitos estéticos do "lugar" de degradação nos sertões goianos}

Artur Neiva e Belisário Pena constituíram com suas narrativas não apenas representações localizadas acerca do interior goiano, contribuíram, ainda, para a construção do pensamento social brasileiro acerca do sertão e suas relações com a nação. Suas narrativas, permeadas com ideias sobre o processo de colonização dos sertões e ao mesmo tempo de estratégias retóricas sobre o projeto civilizador, fomentaram um debate que questionava a vocação daquela região, especialmente do norte de Goiás, para participar da civilização.

Esses médicos fizeram repercutir no texto de Viagem Científica uma crítica severa ao discurso que eles denominaram de retórico e cujo tom ditirâmbico "canta[ria]" louvores a uma grandeza que, inaugurada com Diálogos da Grandeza do Brasil, jamais existira (NEIVA; PENA, 1999, p. 179). Para eles, o problema não havia sido o processo violento de colonização que, aliás, havia sido levado a cabo pelo mameluco, o representante étnico do projeto de nação brasileira, mas o tom romântico que exaltava as riquezas no sertão brasileiro.

A miscigenação entre o branco e o indígena seria, sobretudo para Neiva, o movimento precursor da civilização brasileira e a base na identidade nacional, pois, como pertinentemente esclarece Wanderlei Sebastião de Sousa, para esse médico, “o verdadeiro tipo nacional se estava formando[...] longe do contato com o elemento negro"; [pois o] legado racial brasileiro estaria onde "sobrevivia o mameluco, fruto da união do homem branco, representado pelos bandeirantes, com grupos indígenas". (SOUSA, 2009, p. 260). 
No entanto, a formação étnica de Goiás havia seguido outro caminho, como os próprios médicos esclarecem ao afirmar que "em Goiaz domina[va] o elemento resultante da fusão do negro e do índio, prevalecendo o primeiro; isto no Norte [de Goiás]”. (NEIVA; PENA, 1999, p. 167). Segundo os médicos, “o habitante do norte de Goiás não e[ra] de saúde. Homens de estatura abaixo da média [...] franzinos e pálidos”. (1999, p. 212). Esse é um aspecto determinante na compreensão de Neiva e Pena sobre a viabilidade ou não de os sertões goianos participarem do mundo civilizado, pois, para ambos, faltava ao norte goiano, além de uma natureza pródiga, o elemento humano - o encontro das raças brancas e indígenas - que promovesse o progresso da região.

Em sua visão pessimista, eles defendiam que não tão cedo os sertões goianos veriam chegar a civilização, estando essa ampla região fadada à decadência. Sua imagem privilegiada do atraso e do primitivismo dessa região era a doença, mas essa trazia consigo a marca não da selvageria, mas da barbárie:

Não valerá a pena entrarmos a procurar provar que a água ou a alimentação, nada tem
que ver com bócio em Goiaz; para nós o bócio apresenta uma relação qualquer entre
o homem e o domicílio e se este é constituído à moda dos índios como se vê da
transcrição feita acima [...] ou justamente o oposto, tratar-se de residências bem
construídas de civilizados, os moradores não apresentam o bócio no primeiro caso
nunca e, raras vezes, no segundo exemplo. Ora qualquer que queira achar uma relação
de causa e efeito entre a presença dos barbeiros [protozoário Triatoma Infestans] não
deixará de encontrar bons argumentos em favor dessa hipótese. Nas habitações mal
aparelhadas dos indígenas, as triatomas de modo algum podem proliferar, poderão
penetrar e viver entre as palhas dos colmados, mas as posturas sendo efetuadas
parceladamente e não havendo aglutinação dos ovos como se observa entre os outros
redúvidas, os ovos terão fatalmente que cair ao solo, onde facilmente serão destruídos
principalmente pelas formigas. O mesmo se dará com os domićlios em boas
condições e, onde os hemípteros, devido à circunstância das paredes rebocadas, tão
pouco poderão proliferar. Para desenvolvimento sucessivo de gerações, somente a
cabana, choupana, cafua, ou palhoça de adobos ou a casa de taipa, possuem os
elementos para que tal se dê. Pelas nossas observações o bócio, só existe em uma
condição semi-civilizada; é um mal ligado de qualquer modo à habitação (NEIVA;
PENA, 1999, p. 123-124).

Nesse trecho está registrada a preocupação dos médicos com as formas de contágio do bócio no norte goiano ${ }^{7}$. A diagnose realizada por ambos durante o percurso baseou-se na observação e na experimentalização, mas a catalogação dos sintomas foi construída a partir da ideia de controle social, interessando-nos, a título de representatividade, os critérios utilizados para determinar as causas do bócio em sua vinculação a um tipo de moradia específica: “a

\footnotetext{
${ }^{7}$ Enfermidade causada pela deficiência de sódio e de iodo no organismo. À época da viagem de Neiva e Pena, acreditava-se haver uma relação entre o bócio e a construção das habitações no interior do Brasil, nos moldes da transmissão da doença de Chagas.
} 
cabana, a choupana [...] casa de taipa”, que era a habitação típica dos moradores do norte de Goiás.

Segundo Neiva e Pena, a moradia do norte-goiano, um tipo de moradia intermediária entre a "oca" do selvagem e a casa de alvenaria dos citadinos, hospedava o vetor que esses médicos acreditavam, erroneamente à época, ser o transmissor do bócio. Essa imagem de uma habitação intermediária, construída com materiais típicos do interior goiano - o adobo, a taipa -, compunha, para Neiva e Pena, o quadro que definia a precariedade do sertanejo e sua condição de semicivilizado, ou melhor, de bárbaro. Por outras palavras, a vetorização da doença no norte de Goiás não se encontrava nem no indígena nem no homem branco, mas no sertanejo, habitante de casas intermediárias, semicivilizado: bárbaro.

Sobre a constituição da condição bárbara, Hayden White fornece, em Trópicos do discurso: ensaios sobre a crítica da Cultura (1994), algumas pistas acerca da ficcionalização civilizacional no discurso pré-moderno e, ao fazê-lo, esclarece alguns aspectos que nos interessam discutir sobre como a barbárie sertaneja é uma ficcionalização criada por Neiva e Pena. Segundo White:

[...] assim como os hebreus distinguiam entre judeus, gentios e homens selvagens, também os gregos e romanos faziam distinção entre homens civilizados, bárbaros e homens selvagens. A distinção, em ambos os casos estava ligada à diferença entre os homens que viviam segundo alguma lei (mesmo uma lei falsa) e os que viviam sob nenhuma lei. [...] A maioria dos escritores clássicos reconhecia que, se tribos bárbaras honravam pelo menos a instituição da família, deviam viver segundo algum tipo de lei e, portanto, eram capazes de algum tipo de ordem. Este reconhecimento é provavelmente um meio de indicar uma percepção do fato incômodo de que tribos bárbaras eram capazes de se organizar, pelo menos temporariamente, em grupos suficientemente grandes para constituir uma ameaça à própria civilização. [....] $\mathrm{O}$ bárbaro constituía uma ameaça à sociedade em geral - a civilização, à pureza da raça, à excelência moral, tudo aquilo de que o orgulho do grupo fechado se julgava investido' (WHITE, 1994, p. 186).

A ideia do bárbaro como alguém que não pertence à civilização e que, apesar de possuir alguma organização, encontra-se em condição inferior, parece ser um dos modelos que influenciaram as ficcionalizações realizadas pelos médicos sobre a sociedade norte-goiana. Neiva e Pena escrevem "que qualquer que atravessar aquelas plagas, examinar as condições sociais daquele povo" vai se deparar com "uma organização atrasada e rudimentar; as caatingas estão povoadas de habitantes [que] vivem à margem da civilização; a organização da família legalmente não existe [...]" (NEIVA; PENA, 1999, p. 179). Para esses médicos, os sertões estariam à margem da civilização e, nesse sentido, o bárbaro habitante do norte de Goiás 
ameaçaria o processo civilizacional pelo qual a nação precisava passar, por não possuir os atributos de progresso necessários, tais como uma habitação que não proliferasse doenças.

Para Hayden White, a ficção civilizacional propôs que o semicivilizado, mesmo não sendo selvagem, vivia em estado selvagem e por essa razão foi figurado dentro de modelos que evidenciavam os signos de barbárie como seu constituidor. (WHITE, 1994). Por outras palavras, em White trata-se de pensar os instrumentos discursivos que se sustentam na ideia de que o estado de barbárie se tornaria internalizado pela ansiedade psíquica moderna, típica do processo civilizador (WHITE, 1994). No caso da estrutura de linguagem em Viagem Científica, a internalização passava pela consolidação da ideia de que os sertanejos norte-goianos viviam em estado bárbaro, figurados como semicivilizados, uma "raça inaproveitável", e, nesse sentido, deveriam ser mantidos isolados de qualquer possibilidade de civilização. (NEIVA; PENA; 1999, p. 221)

Neiva e Pena, além da caracterização dos sertanejos como bárbaros, preocuparam-se em desconstruir as formas assumidas pela literatura típica do século XIX, visto que, para eles, no Brasil, o sertão havia adquirido prestígio, por meio da retórica indigenista, a qual assumiu um “modo de contar as cousas que transformou o 'desertão' na Chanaan ${ }^{8}[$ [...]; este feitio moldou o modelo que é seguido até hoje”. (NEIVA; PENA, 1999, p. 179).

As palavras modo, feitio, moldou e modelo delineiam mais que uma preocupação com as formas, expõem um interesse pela discussão dos estilos literários e retóricos que teriam privilegiado, segundo os médicos, certo "modo de contar" sobre os sertões que havia transformado o desertão nas terras de leite e mel das promessas do Antigo Testamento, a Canãa hebraica. Duas questões merecem destaque: primeiro, o efeito estético dessa retórica indigenista seria constituído, segundo Neiva e Pena, com as imagens naturais que vitalizavam o belo e o fértil: “Terras ferazes, natureza pródiga, riquezas excessivas” (1999, p. 179).

Segundo, em oposição à retórica indigenista, os efeitos estéticos mobilizados pelos médicos foram aqueles que tanto evocavam a corrupção do homem, quanto a desolação geográfica que definia o norte de Goiás como desertão. Quanto à ficção da desolação geográfica, já discutimos na sessão anterior; no que concerne à ficção da corrupção do sertanejo norte-goiano, ela está articulada à estética da barbárie construída, segundo Hayden White, a partir do discurso hebraico e que estaria vinculada a uma condição "particularmente moral, a

\footnotetext{
${ }^{8}$ Grifo dos autores.
} 
[uma] manifestação de uma relação específica com Deus [...]. Mas é também - ou antes, é indiscriminadamente - um lugar [...] de um pecado [...] o onde.” (WHITE, 1994, p. 179).

A estética da barbárie se relacionaria primordialmente ao lugar - o onde - da purgação da queda de um "pecador". O “onde do pecado" - o lugar - desvelado por Hayden White merece ser descrito. Segundo ele:

No seu sofrimento Jó degradou-se à condição que antes (Jó 30:3) atribuíra aos seus inimigos (eles/elas solitários; fugiam para o deserto desolado e devastado). O deserto é o caos que jaz no âmago das trevas, um vazio ao qual a alma é enviada na sua degradação, um lugar estéril do qual poucos retornam, ou ninguém (WHITE, 1994, p. 180).

Considerando a relação entre condição e lugar da barbárie, os sertões goianos seriam resultado da fusão entre homens rudes, em condição atávica, e a terra desolada e pobre, $o$ desertão. Do ponto de vista dos efeitos estéticos, a feição do deserto urdida por Neiva e Pena seria o lugar onde o "pecado" seria purgado, à medida que a vida do sertanejo se resumia a "luta[r] asperamente, procurando tirar duma terra ingrata os meios de subsistência[...] da maneira a mais rudimentar (NEIVA; PENA, 1999, p. 179). Ou seja, em uma resposta retórica à retórica indigenista, ambos os médicos concebem o norte goiano com os signos do desertão, poeticamente um pedaço do purgatório bíblico, e, por essa razão, a região jamais caberia na imagem da Canaã bíblica, pois eram o lugar da expiação dos "pecados", onde os sertanejos viveriam na condição de semicivilizados, ou melhor, de bárbaros.

Por outras palavras, sobre o lugar onde o "pecado" seria purgado, ou seja, o onde do "pecado" dentro da ficção civilizacional brasileira, este seria, na perspectiva de Neiva e Pena, o próprio Norte de Goiás “em toda a sua primitividade” (NEIVA; PENA, 1999, p. 179). Restanos compreender qual seria, na concepção desses médicos, a punição pelo "pecado" da barbárie ou da semicivilização, à qual condenaria o sertanejo norte-goiano a viver permanentemente em um "pedaço do purgatório".

\section{Degradações, doenças e tragicidade: a urdidura dantesca do norte-goiano}

A figuração dos sertanejos nas narrativas de Neiva e Pena não permite reconstituir um rosto, uma personagem completa, mas fragmentos por meio dos quais a composição do próprio norte goiano se realizaria. Esses médicos, em seu anseio de propor um quadro que comportasse as imagens dos problemas sociais e naturais dos sertões por eles percorridos, compuseram um relato soturno: 
Em todo o longo percurso apenas três núcleos de população [...] pobres casebres esparsos [...] cujos habitantes são na sua maioria pobres vítimas da tireoide, ancilostomose e do impaludismo. Enfim a solidão, a miséria, o analfabetismo universal, o abandono completo dessa pobre gente, devastada moralmente pelo obscurantismo [...] e física e intelectualmente por terríveis moléstias endêmicas. A raça atual dessa região é inaproveitável (NEIVA; PENA 1999, p. 220-221).

Essa paisagem social, apesar de sua pretensão de objetividade, tem fortes relações com a construção do pensamento social sobre os pobres no século $\mathrm{XX}$, representada na figura polêmica de Monteiro Lobato, que construiu um dos personagens mais emblemáticos da literatura brasileira: o Jeca Tatu. A proximidade entre a composição do homem norte-goiano pelos médicos e a do Jeca Tatu é percebida pelo frade francês José Maria Audrin em $O s$ sertanejos que eu conheci (1963):

Tais são os sertanejos que conhecemos. Que ninguém, pois os tenha como os 'jecas tatus' do autor de Urupês, nem os trate de párias, dignos apenas de compaixão, senão de desprezo! Aceitam corajosos a luta pela vida, não como condenados a miserável destino. Não os acusemos, portanto, como ousaram fazer alguns patrícios de serem opróbrio para a Nação, prejuízo para nossa fama, atraso para nossa marcha (AUDRIN, 1963, p. 09).

Os patrícios que Frei Audrin denunciou serem os acusadores dos sertanejos que viviam no norte-goiano, sem dúvida, são Artur Neiva e Belisário Pena, os quais, segundo o frade, partilhavam com Monteiro Lobato a ideia de que os homens que viviam nos sertões eram párias e a partir desse paralelo produziram seus "relatórios pessimistas" (AUDRIN, 1963, p. 08). A ideia de Audrin é coerente, e a verossimilhança foi detectada pelo próprio frade ao escrever que o "conhecido inventor do Jeca Tatu chegou a afirmar referindo-se ao sertão: 'La nem flores, nem frutas, nem legumes"”. (1963, p. 52).

De fato, a ideia de ausência de tudo, ocasionada por uma pretensa indolência, pode ser estendida, por analogia, ao que escreveram Neiva e Pena sobre Porto Nacional ${ }^{9}$ : que nessa cidade havia "ausência de plantações, de legumes e verduras nos quintais e raras as árvores frutíferas" (NEIVA; PENA, 1999, p. 212). Para esses médicos, a preguiça e a doença andavam lado a lado, porém a ausência de tudo, expressa na imagem dos desertos e das solidões, representava não apenas a aridez do solo ou a indolência dos sertanejos/personagens, mas também a condição de irrecuperabilidade do homem norte-goiano de seu estado semicivilizado: a barbárie.

Bastante exploradas por Hochman (2008), Lima (1999; 2009), Lima e Hochman (2004), as relações entre processo civilizador, políticas de saneamento, a obra de Monteiro Lobato e os

\footnotetext{
${ }^{9}$ Cidade onde residia Audrin quando esses médicos passaram pelos sertões goianos.
} 
trabalhos de médicos brasileiros sobre a proliferação das doenças durante a primeira metade do século XX, são importantes diagnósticos da formação de uma visão sobre os sertões brasileiros. Contudo, o que pretendemos destacar em nosso trabalho é que, para além da possibilidade bastante plausível de que Monteiro Lobato tenha construído seu Jeca Tatu inspirado nas informações "objetivas” consignadas por Neiva e Pena em seus relatórios, é possível que os médicos tenham inspirado sua imagem do sertanejo como uma raça inaproveitável nas ficcionalizações de Lobato $^{10}$.

De fato, há uma dimensão ficcional no texto produzido por Artur Neiva e Belisário Pena. Corroborando essa argumentação, Nísia Trindade Lima escreve que, mesmo que metáforas de origem biológica fossem comuns desde o século XIX em ensaios sociais e políticos, a metáfora da doença adquiriu característica de ideia-força, conforme expressão de Monteiro Lobato, somente a partir do século XX. (LIMA, 2009). No entanto, nossa questão aqui não é encontrar os fios sociais e políticos que sustentam essa metáfora, caso de Lima, mas discutir como, interpenetrada pela composição da natureza como lugar vazio, de solidão ou de desolação, ela - a metáfora da doença - é forjada como a punição do norte-goiano por, segundo ambos os médicos, seu estado de barbárie. Ou seja, como a doença, generalizada a todos os nortegoianos, se tornou a punição que os manteve na "sepultura aberta" que, conforme ambos os médicos, eram esses sertões. (NEIVA; PENA, 1999, p. 174).

A doença, nesse caso, era a condição e o instrumento da punição, visto que "a universalidade da terrível moléstia no Estado [de Goiás] sacrifica[va] de modo incurável a inteligência, a virilidade e a saúde de milhares de infelizes [...]” e, por isso, conforme Neiva e Pena, até mesmo os frades dominicanos concordavam "que Deus faria uma obra de misericórdia se chamasse todos esses infelizes à sua mansão celeste" (NEIVA; PENA, 1999, p. 202). A terrível moléstia referida pelos médicos é o bócio que, em sua forma grave, provocaria o cretinismo, cujos danos seriam a esterilidade e o prejuízo irrecuperável das características cognitivas.

Mas o vínculo que Neiva e Pena fizeram entre doença, incurabilidade e religião estaria mais em nível de ficcionalização dos termos da linguagem do que efetivamente das informações médico-científicas, visto que os signos contidos nas expressões "raça inaproveitável" e "de

\footnotetext{
${ }^{10}$ Segundo Nelson Ibanez, Artur Neiva e Monteiro Lobato tiveram seu primeiro contato entre 1906 e 1909 durante as campanhas de Oswald Cruz pelo interior do país, ou seja, antes da viagem aos sertões realizada pelo primeiro e antes da composição do conto Jeca Tatu pelo segundo; tendo se estreitado a amizade no ano de 1916, quando o médico foi convidado a chefiar o Serviço Sanitário de São Paulo (IBANEZ, 2012).
} 
modo incurável" tecem a imagem de uma população devastada vivendo em uma região natural desolada, cuja poética se consuma em solidão.

O Jeca Tatu de Monteiro Lobato, aquele "homem inadaptável à civilização, [...] que viv[ia] à margem dela na penumbra das zonas fronteiriças" (LOBATO,1990, p. 18), fulgura, no texto de Neiva e Pena, extraído dos purgatórios desolados e devastados, pairando entre a doença e sua personificação, no caso: os sertanejos doentes, "pobres vítimas da tireoide, ancilostomose e do impaludismo" (NEIVA; PENA, 1999, p. 220). Na intertextualidade construída entre os médicos e o literato, não há como estabelecer quem teve a precedência dos temas ou da figuração literária, mas podemos inferir que o norte-goiano, semicivilizado, encontra correspondência no Jeca que vivia à margem da civilização, pois, na impossibilidade desses homens serem recolhidos "à mansão celeste", o que lhes restava era permanecerem territorializados na "sepultura aberta" que eram os sertões goianos.

Artur Neiva e Belisário Pena aprofundaram ainda mais a urdidura trágica: tornando vívida a imagem do sepulcro ao correspondê-la aos cenários literários de Dante Alighieri:

Nós se fôramos poetas, escreveríamos um poema trágico com as descrições das
desgraças, das misérias dos nossos infelizes sertanejos abandonados. A poesia [...]
ficaria apagada pela tragédia, pela desolação e pela miséria dos infelizes habitantes
sertanejos, nossos patrícios. Os nossos filhos que aprendem nas escolas que a vida
simples de nossos sertões é cheia de poesia e de encantos, pela saúde de seus
habitantes, pela fartura do solo, e generosidade da natureza, ficariam sabendo que
nessas regiões se desdobra mais um quadro infernal, que só poderia ser
magistralmente descrito pelo DANTE imortal (NEIVA; PENA, 1999, p. 222).

Embora tenham colocado isso como uma hipótese, as duas metades degradadas que compunham os sertões goianos - natureza e homem - emergiam no enredo dos médicos inspirados na Divina Comédia ${ }^{11}$, inscrevendo, assim, o esse cenário como paisagem dantesca, ou melhor, infernal.

No texto de Neiva e Pena, os termos antitéticos sertão e civilização foram formulados com as nuances literárias mobilizadoras dos signos clássicos da formação cognitiva e temática do Brasil: a oposição entre civilização/paraíso e sertão/inferno. Entretanto, uma atualização dessa semântica se deu em Neiva e Pena porque, para eles, a saída do inferno era impossível, e

\footnotetext{
${ }^{11}$ Escrita pelo florentino Dante Alighieri (1265-1321), a Divina Comédia é o relato da viagem que Dante empreende rumo aos três reinos do "outro mundo": o Inferno, o Purgatório e o Paraíso. Escrito em língua vulgar (toscano) e não em latim, esse grande poema (composto de 3 livros com 33 cantos cada um, com exceção do Inferno, que possui 34). Contudo, segundo Otto Maria Carpeaux, o “"outro mundo’ de Dante é um mundo real [...] Dante foi vencido na política atual da Itália do século XIV; [mas] na política ideal de todos os tempos, o derrotado realizou a sua visão ético-política construindo outro mundo no qual os valores perturbados neste mundo" estão restabelecidos" (CARPEAUX, 2014, p. 17).
} 
a religião confirmava isso por meio da assertiva, atribuída aos frades dominicanos, de que seria melhor que os sertanejos fossem recolhidos por Deus "à mansão celeste".

Extraído das páginas finais de Viagem Científica, o fragmento que faz referência ao Norte de Goiás como um poema dantesco articula duas dimensões do universo trágico. De um lado, aquele que relaciona as relações humanas às condições inevitáveis do sofrimento e, de outro, aquela vinculada ao campo da arte que propõe a elaboração estética das experiências trágicas, sejam elas reais ou imaginadas ${ }^{12}$, caso do poema de Dante Alighieri. O imbricamento dessas ideias compõe a alegoria do norte de Goiás defendida por Neiva e Pena: um quadro infernal constituído como uma sepultura aberta.

Vindos do sertão baiano, a narrativa da chegada de ambos os médicos ao norte-goiano materializou nesse território a alegoria dos "infernos" e registrou a sedução que essa imagem produzia neles, ao escreverem: “estamos em território goiano. Nessa ocasião apreciamos um belo e horrível espetáculo, da campina em chamas, em uma extensão imensa pelo fogo ateado pelos nossos camaradas"13. (NEIVA; PENA, 1999, p. 207).

Atravessar a sepultura abertura que eram os sertões goianos pressupunha de certa forma configurá-los ficcionalmente nas paisagens infernais que faziam incontornáveis os cenários dantescos. Na tessitura dos "círculos infernais" por esses médicos, o fogo 14 "terrível e belo", visto na entrada do norte de Goiás, está relacionado, mais uma vez, aos sentidos trágicos da Divina Comédia, associando-os à transposição dos portões do Inferno por Dante, onde este encontrou a seguinte inscrição: “ANTES DE MIM NÃO FOI CRIADO MAIS NADA SENÃO ETERNO, E ETERNA EU DURO. DEIXAI TODA ESPERANÇA, Ó VÓS QUE ENTRAIS (ALIGUIERI, Canto III, 2014, p. 46).

\footnotetext{
${ }^{12}$ Peter Szondi (1929-1971), em seu Ensaio sobre o trágico, aponta para as mudanças da concepção do trágico a partir do século XVIII. Afastando-se de uma tradição normativa iniciada com a Poética de Aristóteles, que pensava o trágico dentro dos limites formais da tragédia, Szondi reapresenta o conceito sob uma perspectiva filosófica. Das diversas tentativas dos grandes filósofos alemães de estabelecer um conceito universal do trágico, Szondi destaca sua estrutura dialética entre o absoluto e o individual, entre o divino e as suas manifestações, entre o universal e o particular (SZONDI, 2004. Liberto da fôrma da tragédia, o trágico pôde, então, ser encontrado e investigado em outras manifestações artísticas.

${ }^{13}$ Como eram nomeados, a partir do século XIX, os trabalhadores que se ajustavam a um patrão, sob contrato ou não, por uma quantia estipulada previamente e que comumente eram submetidos à escravização por dívida. Essa modalidade de contrato de trabalho e as circunstâncias das situações de escravização são documentadas e discutidas, por exemplo, em Ana Lúcia Silva na obra A Revolução de 30 em Goiás

${ }^{14}$ Esclarecedoramente, a descrição das queimadas é o móvel de Velha Praga ${ }^{14}$, artigo no qual Monteiro Lobato expôs sua visão negativa sobre os sertanejos que habitavam o interior de São Paulo, pois produziam enormes queimadas que "estrug[iam] fragorosa com infernal violência, devorando as tranqueiras, estorricando as mais altas frondes, despejando para o céu golfões de fumo estrelejado de faíscas [...]” (LOBATO, 2010, p. 18).
} 
A queimada "bela e terrível" na entrada de Goiás metaforiza o que o pórtico na entrada do Inferno representou para o autor da Divina Comédia: uma travessia sem esperança de redenção, uma travessia tenebrosa, trágica por fazer emergir na narrativa dos médicos o lugar onde a doença, condição insuperável, territorializava os sertanejos do norte de Goiás.

Por todo o relato do percurso, a presença da retórica médico-científica articula-se à poética dantesca, preenchendo o quadro infernal - a paisagem desolada - com a imagem "de "uma vida quase puramente vegetativa" do homem norte-goiano (NEIVA; PENA, 1999, p. 188). Para Neiva e Pena, o sertanejo, que inconscientemente caiu na sepultura aberta, afundarse-ia irremediavelmente no purgatório/inferno a que estava condenado.

O purgatório de Neiva e Pena não seria um estágio no qual, purgados os "pecados", poder-se-ia vislumbrar o Paraíso ${ }^{15}$. O texto de Viagem Científica delineou os sertões goianos como o inferno ad eternum, contribuindo para essa situação a subjetividade construída pelos médicos para os sertanejos; subjetividade essa que garantia sua permanência no universo "semicivilizado", pois eram dominados por um "natural espírito de rotina [...]; grande número de habitantes, quiçá a maioria, é misoneísta. Praticamente impermeáveis ao progresso". (NEIVA; PENA, 1999, p. 173)

O sofrimento exemplar, aquele trazido como possibilidade de redenção por meio da morte ou agonia do herói trágico, não chegaria ao Norte de Goiás porque os médicos não viam nos sertanejos qualquer capacidade de superação da "barbárie" na qual pretensamente estavam estagnados. Na composição da estética da "barbárie" sertaneja, a impermeabilidade às mudanças, presente, inclusive, na obsolescência da "linguagem [e dos] próprios objetos" tem seu círculo semântico fechado com a alegoria dos sertões como "magnífico hospital para estudo de todas as modalidades de moléstias" (NEIVA; PENA, 1999, p. 216). A territorialização simbólica se completa: O norte de Goiás é território da doença, onde os homens - doentes estão tragicamente condenados a permanecer.

A pertinência da ideia de que o norte de Goiás foi figurado por Artur Neiva e Belisário Pena como uma alegoria trágica de um hospital, concebido como um espaço de observação e pesquisa acerca das doenças, pode ser evidenciada se considerarmos, por exemplo, a concepção de Monteiro Lobato, amigo e interlocutor de ambos os médicos, acerca da viabilidade de sanear aos sertões, o que equivalia à ideia de civilizá-los.

\footnotetext{
15 Para o poeta florentino, as passagens pelo Inferno e pelo Purgatório levariam, por meio do conhecimento e experimentação dos castigos, à purgação e à redenção, que seriam levadas a cabo pela beatitude de Beatriz em uma incursão pelos nove círculos do Paraíso.
} 
No artigo A Casa Rural, publicado originalmente no jornal o Estado de São Paulo e depois em coletânea de título Problema Vital, Jeca Tatu e outros textos (1918) por iniciativa da Sociedade Eugênica de São Paulo e da Liga Pró-Saneamento do Brasil, Lobato resume sua posição ao defender que o "grito de guerra saneamento dos sertões!" não esclarece a extensão do problema: afinal, que sertão seria esse? Para Lobato, "sertão seria o deserto, a terra apenas pisada pelas sentinelas do povoamento" e, mais que isso, "se[riam] reservas de espaço onde o futuro acomodar[ia] o extravasamento da população litorânea", deixando claro que para ele “sanear os sertões e[ra] inexequível." (LOBATO, 2010, p. 88-89)

Na impossibilidade de sanear os sertões, retirando-o da condição de barbárie, restaria ao civilizador atacar "o problema premente e de solução possível [:] o saneamento dos núcleos urbanos" pois antes de pensar nos "sertões despovoados", seria necessário aniquilar o mal [doenças] que atingia o litoral. (LOBATO, 2010, p. 88-89) O tratamento dado ao litoral, elucida em grande medida a concepção de Artur Neiva acerca dos sertões, nas palavras de Lobato: "Em São Paulo, graças à orientação segura do doutor Artur Neiva, já foram lançados os alicerces para que o saneamento não constitua um privilégio exclusivo das cidades. Legislou-se no Código Sanitário também para as fazendas, sítios e sitiocas" (2010, p. 89). Ou seja, os sertões que interessava "salvar", naquele contexto, eram aqueles ligados ao litoral: o interior paulista, por exemplo, com suas fazendas e sítios. Quanto aos sertões distantes do litoral, permaneciam como laboratório, - territórios da doença - espaço de observação e de aprendizado sanitarista.

\section{Considerações Finais}

Artur Neiva e Belisário Pena afirmaram ter escrito Viagem Científica com uma "linguagem insuspeita", por pensarem que, denunciando a caracterização metafórica das demais narrativas sobre o Norte de Goiás, desviariam a atenção de que apresentavam um "uso autoconsciente da metáfora a serviço da auto anulação verbal" de seus próprios discursos, como ensina Hayden White (1992, p. 50). Ou seja, ao apontarem a linguagem poética das demais narrativas sobre o norte goiano, buscavam desviar, por meio dos efeitos da estética naturalista, a atenção de sua própria metaforização da linguagem em tons dantescamente trágicos. 
Nesse sentido, a estratégia buscada foi aprofundar uma linguagem metafórica em estilo naturalista que figurasse os sertões goianos como um lugar - o onde do "pecado" - desolado, o deserto, para o qual se buscava uma solução, mas que, contudo, não havia sido possível encontrar. O homem norte-goiano, por sua vez, foi figurado por Neiva e Pena a partir de uma alegoria primordial: o homem marcado pelas moléstias incuráveis; doenças que atingiam a todos e eram ficcionalizadas como a punição pelo "pecado" irremediável da barbárie.

Se em última instância, não havia uma solução viável, no que concernia a uma política de saneamento, para os sertões goianos, então qual o significado ou relevância das expedições científicas? A relevância é que esses sertões, figurados como sepultura viva, tinham na imagem trágica do sertanejo a personificação da doença e, nesse sentido, havendo doentes, forjava-se o norte de Goiás como território dantesco: um "magnífico hospital para estudo de todas as modalidades de moléstias", espaço adequado, por excelência, ao avanço da ciência médica. (NEIVA; PENA, 1999, p. 216).

Nesse sentido, essa superlativação da linguagem da desolação como marca distintiva de uma realidade pretensamente objetiva fez emergir da narrativa de Neiva e Pena um sertão goiano que não era nem mais e nem menos que um laboratório onde os agentes da Nação buscariam conhecimento suficiente para realizar o saneamento do litoral e de suas adjacências.

A narrativa desses médicos, em última instância, está alicerçada na ideia de que o norte de Goiás, objeto de estudo de comissões e expedições científicas, não figuravam, ao menos até a década de 1950, entre os objetivos civilizacionais práticos do Estado e suas instituições, pois não havia atingido as condições necessárias para sair de seu estado de barbarie. Construir o discurso sobre a região amazônica, especialmente sobre o norte de Goiás, como território da barbárie demandou que o discurso sanitarista de ambos os médicos fosse preenchido com um jogo de linguagens poéticas e retóricas capaz de sustentar a imagem de que essa região era inábil para superar o "atraso" naquela circunstância histórica e, por essa razão, era aceitável e até mesmo desejável que o Estado e a sociedade continuassem a voltar seu olhar apenas para o litoral e mantivesse o hinterland brasileiro vinculado ao signo da insalubridade e à alegoria dantesca "do hospital a céu aberto."

\section{Referências Bibliográficas}

ALIGHIERI, Dante. A Divina Comédia. Tradução, comentários e notas Ítalo Eugenio Mauro; prefácio Otto Maria Carpeaux. 2. ed. São Paulo: Editora 34, 2014. 
AUDRIN, José Maria. Os sertanejos que conheci. Prefácio Alceu Amoroso Lima. Rio de Janeiro: Livraria José Olympio Editora, 1963.

BARTHES, Roland. Aula. Tradução Leyla Perrone-Moisés. 13. ed. São Paulo: Cultrix, 2007.

GUATTARI, Félix; ROLNIK, Sueli. Micropolítica: cartografias do desejo. Petrópolis: Vozes, 1996.

LIMA, Nísia Trindade. Uma brasiliana médica: o Brasil Central na expedição científica de Artur Neiva e Belisário Pena e na viagem ao Tocantins de Júlio Paternostro. História, Ciências, Saúde-Manguinhos, Rio de Janeiro, v. 16, supl. 1, p. 229-248, jul. 2009.

Um sertão chamado Brasil: intelectuais e representação geográfica da identidade nacional. Rio de Janeiro: Iuperj, 2013.

; HOCHMAN, Gilberto. Pouca saúde e muita saúva: sanitarismo, interpretações do Brasil e ciências sociais. In: HOCHMAN, Gilberto; ARMUS, Diego (Org.). Cuidar, controlar, curar: ensaios históricos sobre saúde e doença na América Latina e Caribe. Rio de Janeiro: Editora Fiocruz, 2004.

; SÁ, Dominichi Miranda de. (Org.) Antropologia Brasiliana: ciência e educação na obra de Edgard Roquette-Pinto. Belo Horizonte: Ed. UFMG, 2008.

HAESBAERT, Rogério. Território, poesia e identidade. Espaço e Cultura, n. 3. p. 20-32, 1997. https://www.e-publicacoes.uerj.br/index.php/espacoecultura/article/view/6708

LOBATO, Monteiro. Problema Vital, Jeca Tatu e outros textos. São Paulo: Globo, 2010.

. Urupês. Rio de Janeiro: Editora Globo, 1995.

NEIVA, Artur; PENA, Belisário. Viagem Científica: pelo norte da Bahia, Sudoeste de Pernambuco, Sul do Piauí e de norte a sul de Goiás. Edição Fac-similar. Brasília-DF: Editora do Senado Federal, 1999.

SOUSA, Wanderlei Sebastião. Artur Neiva e a questão nacional nos anos 1910 e 1920 . Revista História, Ciências, Saúde - Manguinhos, Rio de Janeiro, v. 16, supl. 1, p. 249-264, jul. 2009.

SCHWARZ. Lilian Moritz. O Olha naturalista entre a ruptura e a tradição. Revista de Antropologia - USP, v. 35, p. 149-167, 1992.

SCHWEICKARDT, Júlio Cesar. A ciência nos trópicos: as práticas médico-científicas em Manaus na passagem do século XIX para o XX. Revista Pós Ciências Sociais, São Luís, v. 6 n. 12, p. 01-12, 2010.

SILVA, Ana Lúcia da. A Revolução de 30 em Goiás. Goiânia: Cânone Editorial; AGEPEL, 2001. 
SILVA, Raquel Lima. A presença da ironia na ficção naturalista. Revista Letras, Curitiba, n. 82, p. 97-112, set-dez. 2010.

SÜSSEKIND, Flora. O Brasil não é longe daqui. São Paulo: Cia. das Letras, 1990.

SZONDI, Peter. Ensaio sobre o trágico. Rio de Janeiro: Jorge Zahar, 2004.

TÔRRES, Moisés Romanazzi. O Sentido e a Razão de Ser do Paraíso de Dante Alighieri. Mirabilia, n. 12, pp. 39-60, jan./jun. 2011

WHITE, HAYDEN. Trópicos do Discurso: Ensaios sobre a crítica da Cultura. Tradução Alípio Correia de Franca Neto. São Paulo: Editora da Universidade de São Paulo, 1994. 